\title{
Faktor-Faktor yang Mempengaruhi Terjadinya Anemia pada Remaja Putri
}

\author{
Yeni Indrawatiningsih ${ }^{1,2 *}$, ST Aisjah Hamid ${ }^{3}$, Erma Puspita Sari ${ }^{4}$, Heru Listiono ${ }^{5}$ \\ 1,3,4,5 Universitas Kader Bangsa, Jln HM Ryacudu No 887 Ulu Palembang Sumatera Selatan \\ ${ }^{2}$ UPTD Puskesmas Gumawang, Jl.Mayjend Warsito No.1 Desa Gumawang, Belitang, OKU Timur Sumatera Selatan \\ "Correspondence email: yenisbu15@gmail.com
}

\begin{abstract}
Abstrak. Anemia merupakan masalah kesehatan utama masyarakat dunia khususnya di negara berkembang, sekitar 50-80\% anemia disebabkan kekurangan zat besi. Tujuan penelitian ini adalah ingin mengetahui faktor-faktor yang mempengaruhi terjadinya remaja putri. Penelitian ini merupakan survei analitik dengan desain penelitian cross sectional, penelitian dilakukan pada bulan Mei - Juni Tahun 2020 di Desa Sidomakmur Wilayah Puskesmas Gumawang Kabupaten OKU Timur, populasi dalam penelitian ini adalah semua remaja putri yang terdata oleh bidan desa di Desa Sidomakmur yang berjumlah 212 orang dan sampelnya adalah sebagian dari remaja putri yang mengikuti kegiatan Posyandu Remaja Desa Sidomakmur yang berjumlah 98 orang, melalui Proportional Random Sampling, analisis univariat (proporsi), bivariat (uji chi square) dan multivariat (regresi logistik). Hasil analisis menunjukkan bahwa pendidikan remaja ( $\mathrm{p}$ value:0,000), pendapatan orang tua ( $\mathrm{p}$ value:0,012) dan status gizi remaja ( $\mathrm{p}$ vaue:0,000) memiliki hubungan signifikan dengan kejadian anemia pada remaja putri, sedangkan umur remaja $(\mathrm{p}$ value:0,224) tidak memiliki hubungan yang signifikan dengan kejadian anemia pada remaja putri, sedangkan umur remaja. Berdasarkan model akhir analisis multivariat variabel yang paling besar pengaruhnya terhadap status anemia adalah variabel status gizi. Perlunya memberikan penyuluhan-penyuluhan kepada para remaja putri serta memperbaiki cara penyampaian informasi pada saat remaja putri melakukan pemeriksaan tentang cara pencegahan timbulnya anemia, baik berupa pola hidup sehat yang baik dan cara menjaga kesehatan untuk pertumbuhan serta perkembangan remaja putri itu sendiri.
\end{abstract}

Kata kunci: Anemia; Gizi; Pendapatan; Umur

\begin{abstract}
Anemia is a major health problem for people in the world, especially in developing countries, about 50-80\% of anemia is caused by iron deficiency. The purpose of this study was to determine the factors that influence the occurrence of young women. This research is an analytical survey with a cross sectional research design, the study was conducted in May - June 2020 in the village of Sidomakmur, Gumawang Community Health Center, East OKU Regency, the population in this study were all young women recorded by village midwives in Sidomakmur Village, totaling 212 people. and the sample is some of the young women who take part in the Posyandu Youth in Sidomakmur Village, amounting to 98 people, through Proportional Random Sampling, univariate (proportion), bivariate (chi square test) and multivariate (logistic regression) analysis. The results of the analysis showed that adolescent education ( $p$ value: 0,000), parents' income ( $p$ value: 0.012) and adolescent nutritional status ( $p$ vaue: $0,000)$ had a significant relationship with the incidence of anemia in adolescent girls, while adolescent age ( $p$ value: 0.224). ) does not have a significant relationship with the incidence of anemia in adolescent girls, while the age of adolescents. Based on the final model of multivariate analysis, the variable that had the greatest influence on anemia status was the variable nutritional status. It is necessary to provide counseling to young women and improve the way of delivering information when young women conduct examinations on how to prevent anemia, both in the form of a good healthy lifestyle and how to maintain health for the growth and development of young women themselves.
\end{abstract}

Keywords: Anemia; Nutrition; Income; Age

\section{PENDAHULUAN}

Anemia merupakan suatu keadaan dengan kadar hemoglobin dan eritrosit yang lebih rendah dari normal. Anemia gizi besi pada remaja putri beresiko lebih tinggi karena menyebabkan seseorang mengalami penurunan daya tahan tubuh sehingga mudah terkena masalah kesehatan. (Anggoro, 2020)

Anemia adalah keadaan di mana terjadi penurunan jumlah masa eritrosit(red cell mass) yang ditunjukkan oleh penurunan kadar hemoglobin $<11 \mathrm{~g} / \mathrm{dl}$, hematokrit, dan hitung eritrosit (red cell count).(Widodo et al, 2019)

Masa remaja antara usia 10-19 tahun, ialah masa transisi yang dialami seseorang dengan adanya perubahan fisik maupun psikis. Dengan adanya perubahan pada masa remaja menimbulkan beberapa masalah kesehatan. Salah satu masalah kesehatan yang terjadi pada remaja ialah anemia.(Kurniawati dan Tri Sutanto, 2019)

Remaja putri merupakan salah satu kelompok yang rawan menderita anemia, karena pada masa itu mereka juga mengalami menstruasi dan lebih-lebih mereka berpengetahuan kurang terhadap anemia. Pada saat remaja putri mengalami menstruasi yang pertama kali, membutuhkan lebih banyak zat besi untuk menggantikan kehilangan darah akibat menstruasi tersebut. Nilai ambang batas untuk anemia menurut WHO (2015) adalah untuk umur 5-11 th $<11,5 \mathrm{~g} / \mathrm{dl}, 11$ 14 tahun $12,0 \mathrm{~g} / \mathrm{dl}$, remaja diatas 15 tahun untuk anak perempuan < $12 \mathrm{~g} / \mathrm{dl}$ dan anak laki-laki $<13 \mathrm{~g} / \mathrm{dl}$. (Dardjito dan Anandari, 2016) 
Faktor yang dapat mempengaruhi kurangnya pengetahuan remaja putri tentang tablet $\mathrm{Fe}$ antara lain kurangnya informasi yang didapat oleh responden baik dari tenaga kesehatan, media masa, media elektronika maupun dari pihak keluarga, serta kemampuan dari remaja putri untuk memahami informasi yang diberikan. Selain hal tersebut pengetahuan kurang pada remaja putri dikarenakan kurangnya pemberian informasi dari pihak puskesmas setempat yang bekerja sama dengan perangkat desa. (Masthalina, 2015)

Tidak adanya program pengenalan melalui pemberian informasi dan penyuluhan tablet $\mathrm{Fe}$ sebagai suplementasi gizi remaja di desa tersebut bisa jadi sebagai faktor kurangnya pengetahuan mengenai tablet Fe. Kurangnya kegiatan pemberian informasi yang bekerjasama dengan pihak desa menyebabkan pengetahuan dan kesadaran remaja putri mengenai tablet Fe menjadi minim, sehingga banyak remaja putri yang belum melakukan konsumsi tablet Fe. Tingkat pengetahuan seseorang mengenai tablet Fe berpengaruh terhadap perilaku dalam memilih makanan yang mengandung zat besi. (Dardjito dan Anandari, 2016)

Upaya yang dilakukan untuk membantu program yang telah ditetapkan oleh pemerintah Indonesia. Pemberian Tablet Tambah Darah ini bertujuan yang pertama untuk menjalankan program pemerintah tentang pemberian Tablet Tambah Darah pada remaja putri dan untuk mengurangi kejadian anemia pada remaja putri saat menstruasi agar tidak mengganggu saat proses pembelajaran berlangsung dikarenakan saat menstruasi banyak remaja putri yang merasakan lesu, lemes, nyeri dan mengurangi konsentrasi saat belajar.(Kemenkes, 2017)

Ada beberapa faktor yang dapat menyebabkan anemia antara lain adalah status gizi, menstruasi, dan sosial ekonomi. Hasil Riset Kesehatan Dasar (Riskesdas) Nasional tahun 2013 menunjukkan pravelensi anemia pada usia 5-14 tahun sebesar 26,4\%. (Basith et al, 2017)

Faktor yang mempengaruhi anemia pada remaja cukup beragam. Menurut Farida dalam penelitiannya di Kudus, menemukan kasus anemia sebanyak $36.8 \%$ pada sebagian siswi yang mempunyai orang tua dengan tingkat pendapat dan pendidikan rendah. (Arsiyanti \& Nontji, 2015)

Hasil Sensus Penduduk tahun 2010 menunjukkan bahwa 63,4 juta dari jumlah penduduk Indonesia adalah remaja yang terdiri dari remaja putri sebanyak 31,2 juta jiwa (49,30\%). Menurut (Organization, 2013), prevalensi anemia di dunia berkisar antara 40-88\% dengan angka kejadian anemia pada remaja putri terutama di negara-negara berkembang mencapai 53,7\%. (Panyuluh et al, 2018)

Untuk Kabupaten Ogan Komering Ulu Timur khususnya Puskesmas Gumawang melakukan perencanaan pendistribusian tablet tambah darah pada desa-desa seperti di Desa Sidomakmur. Puskesmas Gumawang telah memberikan Tablet Tambah Darah di
Desa Sidomakmur setiap 3 bulan sekali sesuai dengan jumlah remaja putri setempat dengan memberikan pendidikan kesehatan dengan membentuk Posyandu Remaja namun pihak Puskesmas sebelumnya tidak pernah memberikan pendidikan kesehatan tentang pentingnya konsumsi tablet $\mathrm{Fe}$ pada remaja putri dan tidak melakukan pemeriksaan kadar haemoglobin terlebih dahulu pada remaja putri di Desa Sidomakmur. Pihak Puskesmas berkerjasama dengan bidan desa dan perangkat desa untuk pembentukan posyandu remaja putri dan pendistribusian Tablet Tambah Darah, selanjutnya bidan desa bekerja sama dengan kader-kader posyandu yang berada di Desa Sidomakmur untuk pembagian Tablet Tambah Darah yang diberikan setiap 4 minggu sekali pada seluruh remaja putri yang sudah terdata oleh bidan desa dan mendapatkan 1 keping tablet fe per orang, pada saat pembagian Tablet Tambah Darah bidan desa dan kader-kader posyandu membawa air minum dan mewajibkan remaja putri untuk mengkonsumsi Tablet Tambah Darah di Poskesdes. Yang dikonsumsi hanya 1 tablet. Dan sebagaian besar remaja putri yang diberikan tablet tambah darah tidak dikonsumsi dirumah.

Berdasarkan hasil pemeriksaan kadar hemoglobin $(\mathrm{Hb})$ yang dilaksanakan oleh Pelayanan Kesehatan Peduli Remaja (PKPR) Dinas Kesehatan Kabupaten (DKK) OKU Timur terhadap remaja putri menunjukkan bahwa kenaikan presentase dari tiga tahun berturut-turut yaitu 39,8\% (2017), 41,6\% (2018) dan 44,8\% (2019) remaja putri menderita anemia.(Dinkes, 2019)

Anemia pada remaja putri di Kabupaten OKU Timur masih merupakan masalah kesehatan masyarakat, karena prevalensinya $>20 \%$. Sebagai upaya untuk menanggulangi masalah tersebut, Pemerintah Kabupaten OKU Timur menerbitkan Instruksi Bupati OKU Timur dalam pembentukan Pelayanan Kesehatan Peduli Remaja (PKPR) tanggal 04 Juli 2018 dilaksanakan penanda-tanganan komitmen lintas sector dan pelatihan untuk kader remaja.(Dinkes, 2019)

Tujuan penelitian ini adalah ingin mengetahui faktor-faktor yang mempengaruhi terjadinya anemia pada remaja putri.

\section{METODE}

Penelitian ini merupakan survei analitik dengan desain penelitian cross sectional, penelitian dilakukan pada bulan Mei - Juni Tahun 2020 di Desa Sidomakmur Wilayah Puskesmas Gumawang Kabupaten OKU Timur Sumatera Selatan. Variabel independen dalam penelitian ini adalah pendidikan remaja : $<$ SMA dan $\geq$ SMA, umur remaja : remaja awal (jika 1015 Tahun) dan remaja akhir (jika 16-19 Tahun) dan pendapatan orang tua : < UMR (jika < Rp. 3.114.928,-) dan $\geq$ UMR (jika $\geq$ Rp. 3.114.928,-).

Kemudian variabel dependennya adalah status anemia remaja putri: anemia (bila kadar $\mathrm{Hb}<12 \mathrm{~g} / \mathrm{dl}$ ) dan tidak anemia (Jika bila kadar $\mathrm{Hb} \geq 12 \mathrm{~g} / \mathrm{dl}$ ). Populasi 
dalam penelitian ini adalah semua remaja putri yang terdata oleh bidan desa di Desa Sidomakmur yang berjumlah 212 orang dan sampelnya adalah sebagian dari remaja putri yang mengikuti kegiatan Posyandu Remaja Desa Sidomakmur yang berjumlah 98 orang, melalui Proportional Random Sampling. (S. Notoadmodjo, 2018)

Pada penelitian ini pengumpulan data dilakukan dengan cara mengumpulkan data sekunder. Data sekunder yang digunakan dalam penelitian ini adalah check list, rekapitulasi nilai, data kunjungan Posyandu remaja Desa Sidomakmur di wilayah Puskesmas Gumawang Kabupaten OKU Timur tahun 2019. Data diolah dengan program SPSS 22.0 for windows. Analisis data menggunakan analisis univariat, bivariat dan multivariat. Analisis univariat untuk melihat distribusi frekuensi dan proforsi masing masing faktor faktor yang termasuk dalam penelitian. Analisis bivariat untuk mengetahui hubungan variabel independent dan dependent sekaligus untuk melakukan identifikasi variabel yang bermakna dengan dilakukan Uji Chi Square, dengan menggunakan perangkat lunak program SPSS dengan batas kemaknaan $\alpha: 0,05$ keputusan hasil statistic di peroleh dengan cara membandingkan nilai $p$ (p value) dengan nilai $\alpha$. Analisis multivariat untuk melihat hubungan antara variabel dependen dengan beberapa variabel independent dan mencari variabel mana yang paling dominan berhubungan kemudian dilakukan Uji interaksi. Dalam analisis multivariate ini digunakan metode analisis regresi logistic tujuanya adalah untuk mendapatkan variabel yang paling dominan, dikarenakan variabel dependen adalah variabel dikotom dan variabel independent kategorikal. (Hastono, 2001)

\section{HASIL DAN PEMBAHASAN Analisis Univariat}

Penelitian ini dilakukan pada 98 responden. Dari hasil penelitian diperoleh bahwa remaja yang tidak mengalami anemia terdapat lebih banyak yaitu 66 orang $(67,3 \%)$ di bandingkan dengan remaja yang mengalami anemia yang terdapat 32 orang $(32,7 \%)$, kemudian umur remaja dengan kriteria remaja akhir lebih banyak yaitu 59 orang $(60,2 \%)$ di bandingkan remaja awal 39 orang $(39,8 \%)$, kemudian pada variabel pendapatan orang tua dimana pendapatan yang > UMR terdapat lebih banyak yaitu 48 orang $(49,0 \%)$ di bandingkan yang < UMR yaitu 48 orang $(51,0 \%)$, kemudian Status Gizi baik terdapat lebih banyak 91 orang $(92,9 \%)$ dan gizi kurang 7 orang $(7,1 \%)$. (Tabel 1$)$
Table 1. Distribusi Frekuensi Variabel Independen dan Dependen

\begin{tabular}{|c|c|c|c|}
\hline No & Variabel Penelitian & Total & Persentase $(\%)$ \\
\hline \multirow[t]{3}{*}{1} & Pendidikan Remaja & & \\
\hline & 1. $<$ SLTA & 37 & 37,8 \\
\hline & 2. $\geq$ SLTA & 61 & 62,2 \\
\hline \multirow[t]{3}{*}{2} & Umur Remaja & & \\
\hline & 1. Remaja Awal & 39 & 39,8 \\
\hline & 2. Remaja Akhir & 59 & 60,2 \\
\hline \multirow[t]{3}{*}{3} & Pendapatan Orang Tua & & \\
\hline & 1. < UMR & 48 & 49,0 \\
\hline & 2. $\geq \mathrm{UMR}$ & 50 & 51,0 \\
\hline \multirow[t]{3}{*}{4} & Status Gizi Remaja & & \\
\hline & 1. Gizi Kurang & 7 & 7,1 \\
\hline & 2. Gizi Baik & 91 & 92,9 \\
\hline \multirow[t]{3}{*}{5} & Status Anemia & & \\
\hline & 1. Anemia & 32 & 32,7 \\
\hline & 2. Tidak Anemia & 66 & 67,3 \\
\hline
\end{tabular}

Sumber data: hasil penelitian.

\section{Analisis Bivariat}

\section{Hubungan Pendidikan Remaja Dengan Status Anemia}

Hasil analisis hubungan antara pendidikan remaja dengan status anemia diperoleh bahwa ada sebanyak 22 responden $(59,5 \%)$ yang mengalami anemia dan 15 responden $(40,5 \%)$ yang tidak mengalami anemia dari sejumlah 37 remaja yang pendidikannya kurang dari SLTA. Hasil uji statistik diperoleh nilai $p=0,000$, maka dapat disimpulkan bahwa secara statistik pada alpa 0,05 ada hubungan yang signifikan antara pendidikan remaja dengan status anemia pada remaja putri di Desa Sidomakmur Wilayah Puskesmas Gumawang Kabupaten OKU Timur Tahun 2020. Dari analisis diperoleh pula nilai OR : 7,480 artinya remaja yang pendidikannya kurang dari SLTA mempunyai peluang 7,480 kali lebih besar untuk mengalami anemia dibandingkan dengan remaja yang pendidikannya $\geq$ SLTA.

Hal ini serupa dengan hasil penelitian yang dilakukan (Blaney et al, 2015) bahwa remaja putri yang berada pada pendidikan dibawah SLTA sangat rentan dengan anemia yaitu sekitar 57,3\% anak-anak sekolah dasar dan SMP mengalami gejala anemia, beberapa penelitian di berbagai negara menemukan bahwa pendidikan gizi sangat efektif untuk merubah pengetahuan dan sikap remaja putri terhadap makanan, tetapi kurang efektif untuk merubah praktek makan. (Blaney et al., 2015)

Pendidikan kesehatan bermuara pada kemampuan pemeliharaan dan peningkatan kesehatan, baik kesehatan individu maupun masyarakat. Berdasarkan teori tersebut dapat disimpulkan bahwa semakin rendah tingkat pendidikan seseorang maka semakin rendah pula kemampuan pemeliharaan dan peningkatan kesehatan seseorang, yang berarti semakin rendah pula kemampuannya untuk meningkatkan keadaan status gizi agar tidak mengalami anemia. Tingkat kemampuan untuk menerima informasi juga cenderung penduduk 
yang berpendidikan lebih tinggi akan lebih mudah untuk diajak berkonsultasi. (Trihono et al, 2014)

\section{Hubungan Umur Remaja Dengan Status Anemia}

Hasil analisis hubungan antara umur remaja dengan status anemia diperoleh bahwa ada sebanyak 16 responden $(41,0 \%)$ yang mengalami anemia dan 23 responden $(59,0 \%)$ yang tidak mengalami anemia dari sejumlah 39 remaja yang usianya remaja awal. Hasil uji statistik diperoleh nilai $\mathrm{p}=0,224$, maka dapat disimpulkan bahwa secara statistik pada alpa 0,05 tidak ada hubungan yang signifikan antara umur remaja dengan status anemia pada remaja putri di Desa Sidomakmur Wilayah Puskesmas Gumawang Kabupaten OKU Timur Tahun 2020.

Hal ini berbeda dengan penelitian yang dilakukan (Astriana, 2017) menyatakan bahwa pada umur berisiko (35 tahun) berpeluang berisiko mendapatkan anemia 1,8 kali dibandingkan dengan ibu hamil pada umur tidak berisiko karena wanita hamil yang mempunyai umur berisiko dapat merugikan kesehatan ibu maupun pertumbuhan janin, terbukti secara statistik bermakna dengan nilai $\mathrm{p}=0.012$ yang menyatakan ada hubungan usia ibu hamil dengan kejadian anemia.Usia antara 2035 tahun merupakan periode yang paling aman untuk hamil dan melahirkan, sebab pada usia tersebut fungsi alat reproduksi dalam keadaan optimal. Pada kelompok tersebut kurang beresiko komplikasi kehamilan serta memiliki reproduksi yang sehat. Hal ini terkait dengan kondisi biologis dan psikologis dari ibu hamil.(Silalahi et al, 2018)

Umur pada remaja merupakan usia pertumbuhan anak-anak menuju proses kematangan manusia dewasa. Pada umur remaja, terjadi perubahan pada fisik, biologis, dan psikologis seseorang dan terjadi secara terusmenerus selama usia remaja. Ketidakseimbangan antara asupan dan kebutuhan gizi berakibat pada terjadinya masalah gizi, baik gizi kurang maupun gizi lebih. (Nuradhiani et al, 2018)

\section{Hubungan Pendapatan Orang Tua Dengan Status Anemia}

Hasil analisis hubungan antara pendapatan orang tua dengan status anemia diperoleh bahwa ada sebanyak 22 responden $(45,8 \%)$ yang mengalami anemia dan 26 responden $(54,2 \%)$ yang tidak mengalami anemia dari sejumlah 48 remaja yang pendapatan orang tuanya < UMR. Hasil uji statistik diperoleh nilai $p=0,012$, maka dapat disimpulkan bahwa secara statistik pada alpa 0,05 ada hubungan yang signifikan antara pendapatan orang tua dengan status anemia pada remaja putri di Desa Sidomakmur Wilayah Puskesmas Gumawang Kabupaten OKU Timur Tahun 2020. Dari analisis diperoleh pula nilai OR : 3,385 artinya remaja yang pendapatan orang tuanya < UMR mempunyai peluang 3,385 kali lebih besar untuk mengalami anemia dibandingkan dengan remaja yang pendapatan oran tuanya $\geq U M R$.
Hasil penelitian ini sejalan dengan penelitian yang dilakukan oleh (Farinendya et al, 2019) yang meyatakan bahwa pekerjaan orang tua berhubungan dengan terjadinya anemia pada remaja putri. Hal ini dikarenakan bahwa orang tua yang bekerja sebagai pegawai negeri ataupun karyawan mempunyai penghasilan yang cukup atau lebih dalam memberikan makanan bergizi dan seimbang sehingga para remaja tidak ada yang mengalami anemia.

Pembentukan perilaku makan hendaknya dilakukan pada usia dini sehingga bisa menjadi suatu kebiasaan baik. Orang tua memberikan pengaruh besar dalam pengetahuan gizi anak di masa mendatang. (Gibson dan Cooke, 2017) Penelitian di Perancis terhadap anak usia 10 - 19 tahun, dilaporkan bahwa orang tua sebagai sumber utama dalam pemberian informasi gizi, kemudian diikuti oleh guru sekolah, televise serta dokter atau tenaga kesehatan. (De Assis et al., 2005) . Hasil penelitian ini sesuai dengan hasil penelitian (Rozali, 2016) yang menyatakan pekerjaan orang tua berperan dalam status anemia pada remaja putri di Posyandu wilayah kerja Puskesmas Nusukan. Meskipun orang tua yang tidak bekerja memiliki lebih banyak waktu untuk memperhatikan anak tetapi jika pola didik yang diberikan kurang baik seperti dalam pola makan kurang diperhatikan maka akan terjadi masalah anemia (Mentari dan Hermansyah, 2019)

Pekerjaan orang tua sangat berpengaruh langsung terhadap penghasilan /pendapatan di dalam sebuah keluarga dan juga berhubungan erat dengan apa saja yang dibutuhkan kepada keluarganya. Dari sini kita tahu perilaku makan seseorang dalam hal ini remaja dipengaruhi oleh banyak hal, diantaranya adalah pekerjaan orang tua. Pekerjaan orang tua memegang peran yang sangat penting. Makanan apa yang dikonsumsi remaja sangat tergantung dengan makanan apa yang disajikan oleh keluarga dalam hal ini ibu harus mengerti makanan bergizi dan seimbang. Jenis makanan ini juga sangat tergantung dengan berapa besar dana yang tersedia untuk pembelian makanan keluarga. (W. Notoadmodjo, 2012)

\section{Hubungan Status Gizi Remaja Dengan Status Anemia}

Hasil analisis hubungan antara gizi remaja dengan status anemia diperoleh bahwa ada sebanyak 6 responden $(85,7 \%)$ yang mengalami anemia dan 1 responden $(14,3 \%)$ yang tidak mengalami anemia dari sejumlah 7 remaja yang memiliki gizi kurang. Hasil uji statistik diperoleh nilai $\mathrm{p}=0,005$, maka dapat disimpulkan bahwa secara statistik pada alpa 0,05 ada hubungan yang signifikan antara status gizi dengan anemia pada remaja putri di Desa Sidomakmur Wilayah Puskesmas Gumawang Kabupaten OKU Timur Tahun 2020. Dari analisis diperoleh pula nilai OR : 15,000 artinya remaja yang status gizinya kurang mempunyai peluang 15,000 kali lebih besar untuk mengalami 
anemia dibandingkan dengan remaja yang status gizinya baik.

Penyebab prevalensi anemia yang tinggi pada wanita disebabkan banyak faktor antara lain konsumsi zat besi yang tidak cukup dan absorbsi zat besi yang rendah, pendarahan, penyakit malaria, infeksi cacing maupun infeksi lainnya dan remaja putri mengalami siklus menstruasi setiap bulan, (Eicher Miller et al,
2009) namun lebih dari $50 \%$ kasus anemia yang tersebar di seluruh dunia secara langsung disebabkan oleh kurangnya asupan intake zat besi. (Sumarmi \& Adi, 2000) Selain itu remaja putri cenderung melakukan diet ketat untuk mendapatkan tubuh yang ideal dan mengurangi konsumsi makanan sehingga dapat menyebabkan kekurangan zat gizi yang dibutuhkan tubuh termasuk zat besi. (Masthalina, 2015)

Table 2. Hubungan Variabel Independen dengan Variabel Dependen

\begin{tabular}{|c|c|c|c|c|c|c|c|c|c|}
\hline \multirow[t]{3}{*}{ No } & \multirow[t]{3}{*}{ Variabel Independen } & \multicolumn{4}{|c|}{ Status Anemia } & \multirow{2}{*}{\multicolumn{2}{|c|}{ Total }} & \multirow[t]{3}{*}{ Nilai $p$} & \multirow{3}{*}{$\begin{array}{c}\text { Odd Ratio } \\
95 \% \text { CI }\end{array}$} \\
\hline & & \multicolumn{2}{|c|}{$\mathrm{Ya}$} & \multicolumn{2}{|c|}{ Tidak } & & & & \\
\hline & & $\mathrm{n}$ & $\%$ & $\mathrm{n}$ & $\%$ & $\mathrm{~N}$ & $\%$ & & \\
\hline \multirow[t]{3}{*}{1} & Pendidikan Remaja & & & & & & & & \\
\hline & 1. $<$ SLTA & 22 & 59,5 & 15 & 40,5 & 37 & 100 & $0,000^{*}$ & 7,480 \\
\hline & 2. $\geq$ SLTA & 10 & 16,4 & 51 & 83,6 & 61 & 100 & & \\
\hline \multirow[t]{3}{*}{2} & Umur Remaja & & & & & & & & \\
\hline & 1. Remaja Awal & 16 & 41,0 & 23 & 59,0 & 39 & 100 & 0,224 & 1,870 \\
\hline & 2. Remaja Akhir & 16 & 27,1 & 43 & 72,9 & 59 & 100 & & \\
\hline \multirow[t]{3}{*}{3} & Pendapatan Ortu & & & & & & & & \\
\hline & 1. < UMR & 22 & 45,8 & 26 & 54,2 & 48 & 100 & $0,012 *$ & 3,385 \\
\hline & 2. $\geq \mathrm{UMR}$ & 10 & 20,0 & 40 & 80,0 & 50 & 100 & & \\
\hline \multirow[t]{3}{*}{4} & Status Gizi Remaja & & & & & & & & \\
\hline & 1. Gizi Kurang & 6 & 85.7 & 1 & 14,3 & 7 & 100 & $0,005^{*}$ & 15,000 \\
\hline & 2. Gizi Baik & 26 & 28,6 & 65 & 71,4 & 91 & 100 & & \\
\hline
\end{tabular}

Sumber data: hasil penelitian.

\section{Analisis Multivariat}

\section{Pemilihan Variabel Kandidat Multivariat}

Pemilihan variabel kandidat dilakukan melalui analisis bivariat. .Hasil uji bivariat yang mempunyai nilai $\mathrm{p} \leq 0,25$ maka variabel tersebut dapat masuk ke dalam model multivariate, sedangkan variabel yang mempunyai nilai $\mathrm{p}>0,25$ tidak di ikutsertakan dalam analisis multivariate. Dalam penelitian ini ada 4 variabel independent yang masuk dalam analisis multivariate yaitu, pendidikan remaja, umur remaja, pendapatan orang tua dan status gizi remaja seperti pada table 3 berikut ini:

Tabel 3. Variabel Independent yang Masuk Kandidat Model Multivariat.

\begin{tabular}{clc}
\hline No & $\begin{array}{l}\text { Faktor Berpengaruh Terhadap Status } \\
\text { Anemia }\end{array}$ & p value \\
\hline 1 & Pendidikan Remaja & 0,000 \\
2 & Umur Remaja & 0,153 \\
3 & Pendapatan Orang Tua & 0,006 \\
4 & Status Gizi Remaja & 0,002 \\
\hline
\end{tabular}

Sumber data: hasil penelitian.

\section{Pembuatan Model Faktor Penentu Terhadap Status Anemia}

Dari hasil analisis regresi logistic pada model akhir (fit model) didapat 2 variabel yang bermakna secara statistic hubunganya dengan status gizi remaja. Kedua variabel tersebut adalah variabel pendidikan remaja dan status gizi remaja. Kemudian untuk mengetahui variabel mana yang paling dominan pengaruhnya terhadap status anemia remaja dapat dilihat pada nilai Exp (B). Dari model akhir ternyata variabel yang paling besar pengaruhnya terhadap status anemia adalah variabel status gizi.(Tabel 4).

Penyebab prevalensi anemia yang tinggi pada wanita disebabkan banyak faktor antara lain konsumsi zat besi yang tidak cukup dan absorbsi zat besi yang rendah, pendarahan, penyakit malaria, infeksi cacing maupun infeksi lainnya dan remaja putri mengalami siklus menstruasi setiap bulan. (Eicher-Miller et al., 2009)

Tabel 4. Model Akhir Regresi Logistik antara 2 Variabel Independen Dengan Status Anemia

\begin{tabular}{lcccc}
\hline \multicolumn{1}{c}{ Variabel } & B & P Wald & OR & 95 \% CI \\
\hline Pendidikan Remaja & 1,927 & 0,000 & 6,870 & $2,582-18,276$ \\
Status Gizi Remaja & 2,461 & 0,037 & 11,711 & $1,163-117,899$ \\
Constant & $-7,016$ & 0,004 & 0,001 & \\
\hline
\end{tabular}

Sumber data: hasil penelitian.

\section{Uji Interaksi antar Variabel Independen}

Dari uji interaksi, terlihat tidak ada interaksi antara pendidikan remaja dengan status gizi remaja ( $\mathrm{p}$ value : 0,999). Keadaan semacam ini memberikan petunjuk bahwa hubungan pendidikan remaja dengan status anemia tidak memberikan efek yang berbeda untuk remaja yang status gizinya baik dan yang kurang baik. (Tabel 5). 
Yeni Indrawatiningsih, ST Aisjah Hamid, Erma Puspita Sari dan Heru Listiono, Faktor-Faktor yang Mempengaruhi Terjadinya Anemia Pada Remaja Putri

Tabel 5. Uji Interaksi Antara Pendidikan Remaja dan Status Gizi Terhadap Status Anemia

\begin{tabular}{lccc}
\hline INTERAKSI & $\mathbf{- 2}$ Loglikehood & G & P value \\
\hline Pendidikan & 95,696 & 28,116 & 0,999 \\
Status Gizi & 95,696 & 28,116 & 0,999 \\
Pendidikan*Status & 95,696 & 28,116 & 0,999 \\
Gizi & & & \\
\hline
\end{tabular}

Sumber data: hasil penelitian

Tidak adanya interaksi antara pendidikan dan status gizi dalam menimbulkan kejadian anemia disini dikarenakan ada beberapa remaja yang pendidikannya rendah tetapi status gizinya baik dan ada beberapa yang pendidikannya tinggi tetapi status gizinya tidak baik.

Anemia disebabkan oleh kurangnya zat besi dalam tubuh sehingga kebutuhan besi untuk eritropoesis tidak cukup yang ditandai dengan gambaran sel darah merah yang hipokrom mikrositik, kadar besi serum dan saturasi (jenuh) transferin menurun, akan berperan penting mengikat besi total (TIBC) meninggi dan cadangan besi dalam sumsum tulang dan tempat lain sangat kurang atau tidak ada sama sekali. (Ella dan Mustafidah)

Asupan energi pada remaja sangat mempengaruhi pertumbuhaan tubuh, jika asupan tidak kuat dapat menyebabkan seluruh fungsional remaja ikut menderita. Antara lain, derajat metabolisme yang buruk, tingkat efektifitas, tampilan fisik, dan kematangan seksual. Usia remaja merupakan usia dimana terdapat perubahanperubahan hormonal dimana perubahan struktur fisik dan psikologis mengalami perubahan drastis. Masalah gizi yang utama yang dialami oleh para remaja diantaranya yaitu anemia defisiensi zat besi, kelebihan berat badan/obesitas dan kekurangan zat gizi. Hal ini berkaitan dengan meningkatnya konsumsi makanan olahan yang nilai gizinya kurang, namun memiliki banyak kalori sebagai faktor pemicu obesitas pada usia remaja. Konsumsi jenis-jenis junk food merupakan penyebab para remaja rentan sekali kekurangan zat gizi. (Dahlia et al, 2016)

\section{SIMPULAN}

Hasil analisis menunjukkan bahwa pendidikan remaja ( $p$ value:0,000), pendapatan orang tua ( $p$ value:0,012) dan status gizi remaja (p vaue: 0,005 ) memiliki hubungan signifikan dengan kejadian anemia pada remaja putri, sedangkan umur remaja ( $\mathrm{p}$ value:0,224) tidak memiliki hubungan yang signifikan dengan kejadian anemia pada remaja putri. Berdasarkan model akhir analisis multivariat variabel yang paling besar pengaruhnya terhadap status anemia adalah variabel status gizi demngan nilai OR : 11,711 dimana remaja yang memiliki status gizi kurang memiliki risiko 11,711 kali lebih besar untuk mengalami anemia dibandingkan remaja yang status gizinya baik.

\section{DAFTAR PUSTAKA}

Anggoro, S. (2020). Factors Affecting the Event of Anemia in High School Students. Jurnal Ilmiah Permas: Jurnal Ilmiah STIKES Kendal, 10(3), 341-350.

Arsiyanti, H. V., \& Nontji, W. (2015). Faktor Risiko anemia pada Remaja Putri di Kecamatan Bontoramba Kabupaten Jeneponto. Naskah Publikasi.

Astriana, W. (2017). Kejadian anemia pada ibu hamil ditinjau dari paritas dan usia. Aisyah: Jurnal Ilmu Kesehatan, 2(2), 217394.

Basith, A., Agustina, R., \& Diani, N. (2017). Faktorfaktor yang berhubungan dengan kejadian anemia pada remaja putri. Dunia Keperawatan: Jurnal Keperawatan dan Kesehatan, 5(1), 1-10.

Blaney, S., Februhartanty, J., \& Sukotjo, S. (2015). Feeding practices among Indonesian children above six months of age: a literature review on their potential determinants (part 2). Asia Pacific Journal of Clinical Nutrition, 24(1), 28.

Dahlia, M., Rusilanti, R., \& Sachriani, S. (2016). Pengembangan Media DVD Interaktif dan Video tentang Menu Sehat Seimbang Balita untuk Kader Posyandu. Jurnal Pendidikan Teknologi dan Kejuruan, 23(1), 40-44.

Dardjito, E., \& Anandari, D. (2016). Anemia gizi besi pada remaja putri di wilayah Kabupaten Banyumas. Kesmas Indonesia: Jurnal Ilmiah Kesehatan Masyarakat, 8(1), 16-31.

De Assis, M., Rolland-Cachera, M. F., Grosseman, S., de Vasconcelos, F., Luna, M. E. P., Calvo, M., ... Bellisle, F. (2005). Obesity, overweight and thinness in schoolchildren of the city of Florianopolis, Southern Brazil. European Journal of Clinical Nutrition, 59(9), 1015-1021.

Dinkes. (2019). Profil Dinas Keskehata Oku Timur.

Eicher-Miller, H. A., Mason, A. C., Weaver, C. M., McCabe, G. P., \& Boushey, C. J. (2009). Food insecurity is associated with iron deficiency anemia in US adolescents. Am J Clin Nutr, 90(5), 1358-1371.

ELLA, F., \& MUSTAFIDAH, H. HUBUNGAN ANTARA STATUS GIZI DENGAN KEJADIAN ANEMIA PADA REMAJA PUTRI DI KELAS XI.

Farinendya, A., Muniroh, L., \& Buanasita, A. (2019). Hubungan Tingkat Kecukupan Zat Gizi dan Siklus Menstruasi dengan Anemia pada Remaja Putri. Amerta Nutrition, 3(4), 298-304.

Gibson, E. L., \& Cooke, L. (2017). Understanding food fussiness and its implications for food choice, health, weight and interventions in young children: the impact of professor Jane Wardle. Current obesity reports, 6(1), 46-56.

Hastono, S. P. (2001). Analisis data. Depok: Fakultas Kesehatan Masyarakat Universitas Indonesia. 
Yeni Indrawatiningsih, ST Aisjah Hamid, Erma Puspita Sari dan Heru Listiono, Faktor-Faktor yang Mempengaruhi

Kemenkes. (2017). Data Kesehatan Dasar Indonesia Tahun 2017.

Kurniawati, D., \& TRI SUTANTO, H. (2019). FAKTOR-FAKTOR YANG MEMPENGARUHI ANEMIA REMAJA PUTRI DENGAN MENGGUNAKAN BAYESIAN REGRESI LOGISTIK DAN ALGORITMA METROPOLISHASTING. Mathunesa: Jurnal Ilmiah Matematika, 7(1).

Masthalina, H. (2015). Pola Konsumsi (faktor inhibitor dan enhancer fe) terhadap Status Anemia Remaja Putri. KEMAS: Jurnal Kesehatan Masyarakat, 11(1), 80-86.

Mentari, S., \& Hermansyah, A. (2019). Faktor-faktor yang berhubungan dengan status stunting anak usia 24-59 bulan di wilayah kerja UPK puskesmas Siantan Hulu. Pontianak Nutrition Journal (PNJ), 1(1), 1-5.

Notoadmodjo, S. (2018). Metodologi Penelitian Kesehatan: Rineka Cipta.

Notoadmodjo, W. (2012). Promosi Kesehatan untuk Kebidanan. Jakarta: renika Cipta.

Nuradhiani, A., Briawan, D., \& Dwiriani, C. M. (2018). Dukungan guru meningkatkan kepatuhan konsumsi tablet tambah darah pada remaja putri di Kota Bogor. Jurnal Gizi dan Pangan, 12(3), 153160.

Organization, W. H. (2013). Transforming and scaling up health professionals' education and training: World Health Organization guidelines 2013: World Health Organization.

Panyuluh, D. C., Prabamukti, P. N., \& Riyanti, E. (2018). Faktor-faktor yang berhubungan dengan perilaku penyebab anemia pada santriwati Pondok Pesantren Darul Ulum Kabupaten Kendal. Jurnal Kesehatan Masyarakat (e-Journal), 6(2), 156-162.

Rozali, N. A. (2016). Peranan pendidikan, pekerjaan ibu dan pendapatan keluarga terhadap status gizi balita di posyandu $R w 24$ dan 08 wilayah kerja puskesmas nusukan kota surakarta. Universitas Muhammadiyah Surakarta.

Silalahi, V., Putri, R. M., \& Ariani, N. L. (2018). Peranan Pendidikan Gizi pada Guru dalam Meningkatkan Asupan Sayur dan Buah Anak Sekolah. J. Ilm. Ilmu Kesehat, 6, 253-266.

Sumarmi, S., \& Adi, A. C. (2000). Laporan Penelitian Sosialisasi Upaya Perbaikan Menu Makanan Anemia Defisiensi pada Ibu Hamil. Surabaya: Pusat Penelitian dan Pengembangan Gizi Lemlit Unair.

Trihono, P. P., Prayitno, A., Muktiarti, D., \& Soebadi, A. (2014). Pendekatan Holistik Penyakit Kronik Pada Anak untuk Meningkatkan Kualitas Hidup. Edisi, 1, 104-111.

Widodo, M. D., Candra, L., \& Rialita, F. (2019). Determinan Kejadian Anemia Pada Remaja Putri Di SMA Negeri 1 Reteh Kecamatan Reteh
Kabupaten Indragiri Hilir Tahun 2019. Photon: Jurnal Sain dan Kesehatan, 9(2), 88-98. 